\section{Literature cited}

1) Bernal, J. D., D. R. Dasgupta and A. L. Mackay : Clay Mineral Bull., 4, 15 (1959)

2) Izumi, K., A. Yamada, T. Mukushi and S. Takahashi: Kagaku Kogaku Ronbunshu,9,270(1983)

3) Kagaku Kogaku Kyokai (ed.): "Chemical Engineers Handbook, 4th Ed.," p.420, Maruzen, Tokyo
(1978)

4) Kiyama, M.: Powder \& Powder Metallurgy, Japan, 23, 77 (1976)

5) Knudsen, J. G.: Chem Eng. Prog., 80, 63 (1984)

6) Misawa, T., K. Hashimoto and S. Shimodaira Boshoku Gijutsu, 23, 17 (1974)

7) Takada, T.: Kagaku Kogyo, 11, 1145 (1976)

\title{
Formation of Oxides and Hydroxides of Iron in High-Temperature Water
}

\author{
Akira Yamada, Toshio Sawa and Kenkichi Izumi \\ Hitachi Research Laboratory, Hitachi, Ltd., Hitachi 317
}

\begin{abstract}
Key Words: Heat Exchanger, Fouling, Sludge, Corrosion Products, Iron Compound, Reaction Rate Constant

The heat transfer coefficient of heat exchangers decreases with operation time due to the fouling of heat transfer surfaces. The fouling substance consists of the corrosion products produced by the plant construction materials, and their constituents are mainly oxides and hydroxides of iron. The mechanism of formation of these iron oxides in water at high temperature was experimentally investigated. The experiments showed that the main products are $\mathrm{Fe}_{3} \mathrm{O}_{4}, \alpha-\mathrm{Fe}_{2} \mathrm{O}_{3}$, and amorphous iron oxides. The products were morphologically controlled by the water temperature and the ratio of dissolved oxygen to $\mathrm{Fe}(\mathbb{I})$ ion concentration in water. In addition, the rate constants of the oxidation of $\mathrm{Fe}(\mathrm{II})$ ion in water were obtained.
\end{abstract}

\section{KOH触媒処理チャーの流動層水性ガス化反応 ${ }^{\dagger}$}

\author{
島田浩次・沢井篤司・原弘 \\ 室蘭工業大学 化学工学科 ${ }^{\dagger+}$
}

石炭の接触水性ガス化に関する報告は数多くあり, 中 であカリウムが有効な触媒であることは既に広く知られ ている ${ }^{5,7,8)}$. 本実験では, 流動層による水性ガス化反応 を行い, 触媒添加于ャ一の乾留条件と触媒量に対し知見 が得られたので報告する.

\section{1. ガス化試料}

実験には, 粒度 $3.5 \times 10^{-4} \sim 7.0 \times 10^{-4} \mathrm{~m}$ 範囲の非粘結

\footnotetext{
† 1986年5月 8 日受理 ; 化学工学協会第 50 年会

（横浜，1985年 3 月）にて発表

\# $干 050$ 室蘭市水元町 27-1
}

第13巻 第 2 号 (1987)
性太平洋炭を用いた, その物性值をTable 1に示した. 石炭への触媒添加は含浸法により行った．5〜30wt\%の 範囲の水酸化カリウム水溶液中に石炭を混入し, 24 時間 $100^{\circ} \mathrm{C} \pm 10^{\circ} \mathrm{C}$ の恒温槽中で水分を蒸発させ, 種々の濃度 の触媒含浸石炭を作成した. 乙れらの石炭をアルゴン雾 囲気流動層中で $500^{\circ} \mathrm{C}$ から $1000^{\circ} \mathrm{C}$ の温度でそれぞれ 10 分 間乾留し, 生成したチャーを水性ガス化試料 $\mathrm{N}$ する. また, 触媒効果を詳細に検討するために脱灰と触媒を均

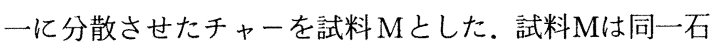
炭をボールミルで平均粒径 $3 \times 10^{-6} \mathrm{~m}$ まで湿式粉砕し, オ イルアグロメレーションと硝酸処理により灰分 $15.5 \mathrm{wt} \%$ 
Table 1 Proximate and ultimate analysis of Taiheiyo coal

Proximate analysis [wt \%] Ultimate analysis[wt \%]

$\begin{array}{lrcr}\text { Volatile matter } & 39.0 & \text { C } & 64.8 \\ \text { Fixed carbon } & 40.3 & \text { H } & 5.2 \\ \text { Moisture } & 5.2 & \text { N.O.S } & 14.5 \\ \text { Ash } & 15.5 & & \end{array}$

を $4.8 \mathrm{wt} \%$ まで脱灰した. 脱灰石炭は水酸化カリウム水 溶液に含浸, 乾燥を経て, 微粉末を $10^{-4} \mathrm{~m}^{2}$ のディスク型 のペレットに $2.0 \times 10^{12} \mathrm{~Pa}$ で加圧成型した. 成型処理石炭 は試料 $\mathrm{N}$ と同一条件で乾留され, 同一粒径に粉砕調製し た. チャー中のカリウム濃度の測定は, 理学電機製蛍光 X線分析装置により行った。

\section{2. 実験装置および方法}

本実験に用いた流動層ガス化装置の概略図を Fig.1 に 示した，反応管は長さ $3.00 \times 10^{-1} \mathrm{~m}$, 内径 $2.5 \times 10^{-2} \mathrm{~m}$ の SUS 316ステンレス管である. 管内底部にガス分散板と

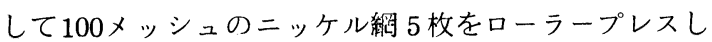
たものを用い，さらにガス分散板上に粒径 $7.3 \times 10^{-4}$ $8.3 \times 10^{-4} \mathrm{~m}$ の範囲の球状アルミナ約 $1.0 \times 10^{-2} \mathrm{~kg}$ を敷き ガスの整流をした．流動層は球状アルミナ上層に粒径 $1.07 \times 10^{-4} \sim 2.40 \times 10^{-4} \mathrm{~m}$ の範囲のケイ砂約 $2.0 \times 10^{-2} \mathrm{~kg}$ を充填しアルゴンガス $3.3 \times 10^{-6} \mathrm{~m}^{3} \cdot \mathrm{s}^{-1}$ 純水 $5.5 \times 10^{-8} \mathrm{~m}^{3}$ . $\mathrm{s}^{-1}$ でケイ砂の流動層を形成させている. 反応温度の設 定は触媒処理于ャーと無触媒于ャーとの反応性の違いを 明確にさせることと, ガス分析上の精度を考慮し, 予備 実験の結果水性ガス化反応としては比較的低い温度 800 ${ }^{\circ} \mathrm{C}$ した. $800^{\circ} \mathrm{Cでの}$ 水蒸気とアルゴンによる混合ガス の流動層内の空塔基準線流速は $7.60 \times 10^{-2} \mathrm{~m} \cdot \mathrm{s}^{-1}$ でケイ 砂基準の $U / U m f$ は 1.4 1.6の範囲にあることを既に報 告している ${ }^{6)}$. ここで, 本実験の水蒸気分圧は $62 \mathrm{kPa}$ 亿相 当する ${ }^{1)}$. ガス化は層内の流動と温度が定常に達してから, チャーを反応管上部のホッパーより瞬時に投入して行っ た。なお，本実験の操作範囲において，チャ一投入量に 及ぼす反応速度の影響を検討するためにチャ一投入量を $3.0 \times 10^{-4} \sim 1.5 \times 10^{-3} \mathrm{~kg}$ の範囲で行ったが反応速度には この範囲の影響が認められなかったので，本実験では投 入量を $5.0 \times 10^{-4} \mathrm{~kg}$ として実験を行った ${ }^{4,6)}$. 投入と同時 に発生するガスを経時的にサンプリングし, TCD型ガス クロマトグラフで分析を行った．また，発生したガスの 全量をサンプルバックで捕集し炭素量計算の指標に 用いた。転化率 $X$ の計算は, 反応開始から任意時間 $t$ ま でに反応した累積炭素量を総炭素量で割った值である. 反応開始から任意時間 $t$ までの累積炭素量は Fig.2のガ ス発生速度曲線の図積分により求めるが, 図積分はコン

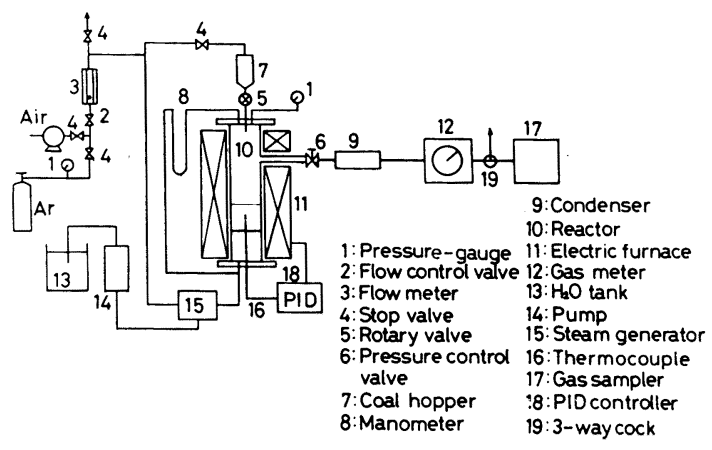

Fig.1 Experimental apparatus

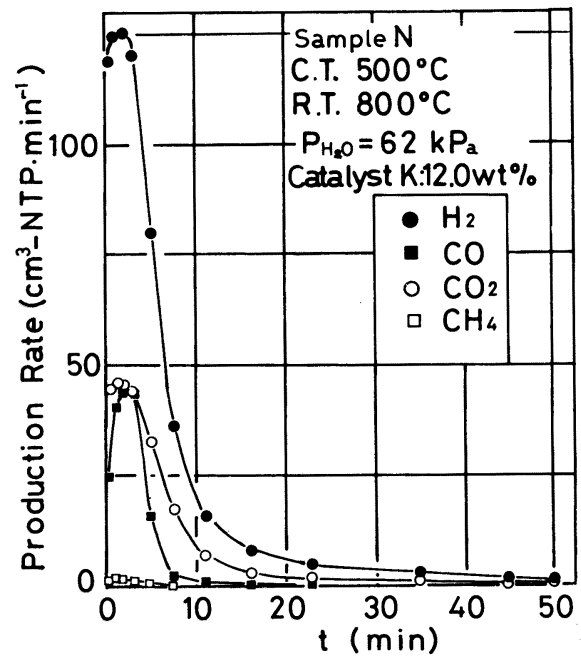

Fig.2 Production rate of each gaseous component in steam gasification

ピューター (PC-9801E)の図形処理で行った．乙てでコ ンピューターの図形処理によって得た累積炭素量とサン プルバックで捕集した発生ガスより求めた累積炭素量と の誤差は土 $2 \%$ 以内であった。 なお，総炭素量は累積炭素 量と末反応チャーを完全燃焼させて得られた炭素量との 和亡して求めた。 また, $500^{\circ} \mathrm{C}$ の処理チャーを水性ガス 化温度 $800^{\circ} \mathrm{C}$ で反応させた場合, 発生ガス中にはガス化 反応によって発生するガス以外に反応によらないガス量 すなわち $500^{\circ} \mathrm{C}$ 処理チャ一中に残存する揮発分が含まれ ている. ての反応によらない揮発分を次のように算出し た. $500^{\circ} \mathrm{C}$ 処理チャーを $800^{\circ} \mathrm{C}$ の温度でアルゴン中 10 分間 乾留し, 発生したガス量を反応によらない乾留楎発分と してあらかじめ求めた。 したがって, $500^{\circ} \mathrm{C}$ 処理チャ一 に関しては水性ガス化温度 $800^{\circ} \mathrm{C}$ のガス発生量からあら かじめ求めた乾留揮発分を差し引いて補正した。

\section{3. 実験結果および考察}

触媒処理チャーの水性ガス化反応に及ぼす乾留温度の 効果を検討するために乾留条件を $500^{\circ} \mathrm{C}$ から $1000^{\circ} \mathrm{C}$ 温 


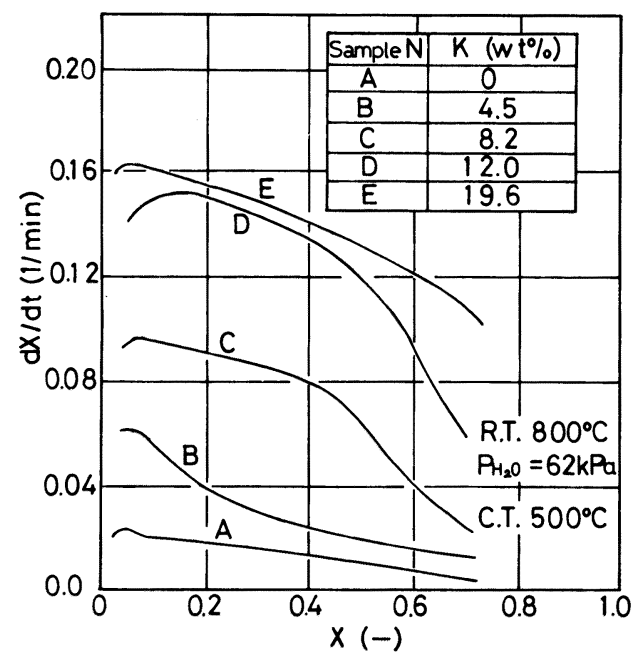

Fig.3 Effect of potassium content on $d X / d t$ and $X$

度範囲でチャーを作成し, 水性ガス化反応を $800^{\circ} \mathrm{C} て ゙$ 行 った. Fig. 2 に一例として試料 $\mathrm{N}$ 亿つて乾留温度 500 ${ }^{\circ} \mathrm{C}$, カリウム濃度 $12.0 \mathrm{wt} \%$ のチャ一の水性ガス化反応に よる各成分の発生ガス量と時間の関係を示した。な打図 中C.T., R.T.はそれぞれ乾留温度, 水性ガス化温度を表 している，また図は $800^{\circ} \mathrm{C}$ による乾留揮発分を差し引い

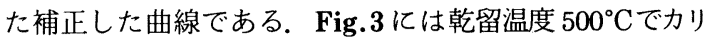
ウム濃度を変えた 5 種類のチャ一の反応速度 $d X / d t$ 之転 化率 $X$ の関係を示した。乙てで, 転化率扰よび反応速度 は Fig. 2 亿基づいたガス発生曲線の図形処理から求めた。

Fig.4 亿乾留温度 $500^{\circ} \mathrm{C}$ および $900^{\circ} \mathrm{C}$ の場合の転化率 $X=0.2$ の時の反応速度に及ぼす触媒量の関係を示した. 図よりいずれの処理チャーにおいても, 触媒添加量の增 加之共に反応速度は増加するが，触媒カリウム量 $13 \mathrm{wt} \%$ 以上では触媒添加量を増加しても反応速度の増加はみら れない。また, $500^{\circ} \mathrm{C}$ 処理于ャ一の反応速度は $900^{\circ} \mathrm{C}$ 処 理チャーよりも高い值を示した. Fig.5亿触媒量13.2 $13.4 \mathrm{wt} \%$ 転化率 $X=0.2$ の時の反応速度に及ぼす乾留温度 の関係を示した。図より乾留温度が $500^{\circ} \mathrm{C}$ から $800^{\circ} \mathrm{C}$ ま での反応速度は乾留温度の上昇と共に多少減少傾向にあ るが，乾留温度が $900^{\circ} \mathrm{C}$ 以上になると反応速度の急激な 減少を示している.

この処理チャ一の反応速度の違いを転化率 $X=0.2$ の比 表面積と X 線回折から検討を行った。 $500^{\circ} \mathrm{C}, 900^{\circ} \mathrm{C}$ 処理 チャー，打よび無触媒チャ一の転化率 $X=0.2$ の時の比表 面積をTable 2に示した。測定は窒素吸着B.E.T. 法で行 った，表より転化率 $X=0.2$ における処理チャーおよび無 触媒チャ一の比表面積はいずれも $2.0 \times 10^{5} \sim 3.0 \times 10^{5} \mathrm{~m}^{2}$ / kg-charでほぼ同一值である. したがって, 処理チャ一

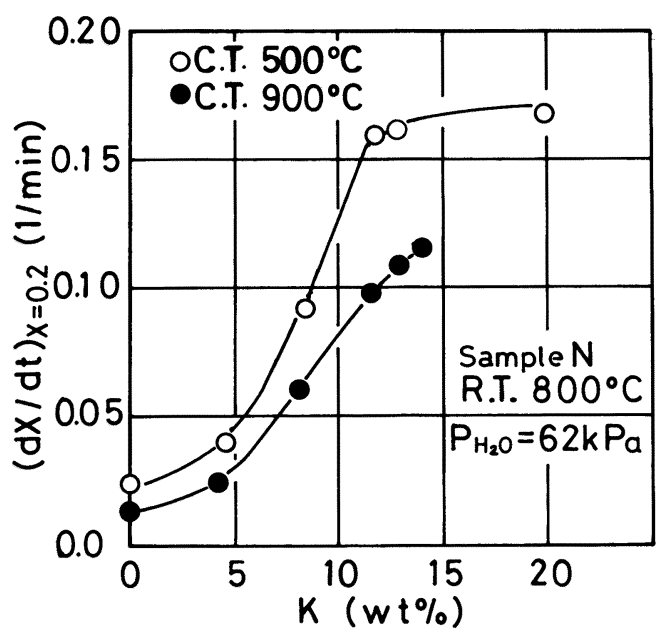

Fig.4 Effect of potassium content on $d X / d t$ at $X=0.2$

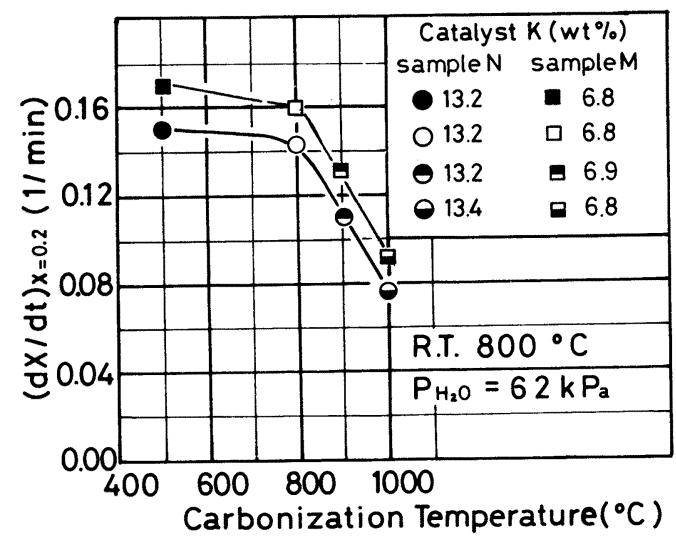

Fig.5 Effect of carbonization temperatures on $d X / d t$ at $X=0.2$

の反応速度の違いに及ぼす比表面積の効果は無視できる あの之思われる. また, X線回折の結果の一例を Fig. 6 に示した。図は触媒量 $13.2 \sim 13.4 \mathrm{wt} \%$ 乾留温度 $500^{\circ} \mathrm{C}$, $800^{\circ} \mathrm{C}, 900^{\circ} \mathrm{C}$, および $1000^{\circ} \mathrm{C}$ で 10 分間処理した 4 種類の チャーと, $500^{\circ} \mathrm{C}$ 処理チャーを水性ガス化温度 $800^{\circ} \mathrm{C}$ で 反応させた転化率 $X=0.2$ の時のチャーのそれぞれの X線 回折パターンである. 図より乾留温度 $500^{\circ} \mathrm{C}$ では $2 \theta=44^{\circ}$ の (10)面にチャ一の構造変化を示すピークが表れていな いが，乾留温度 $800^{\circ} \mathrm{C}$ および $500^{\circ} \mathrm{C}$ 処理于ャ一の転化率 $X=0.2$ のそれぞれのチャーでは構造変化を示すピークの 傾向が表れてきている. $900^{\circ} \mathrm{C} て ゙ は$ 明確にピークを示し, $1000^{\circ} \mathrm{C}$ ではさらにピークがシャープになっている.

以上は試料 $\mathrm{N}$ 亿ついて行った結果であるが，試料Mす なわち脱灰させ, カリウム濃度 $6.8 \mathrm{wt} \%$ の触媒を均一に 分散させたチャ一を同様の実験条件で水性ガス化反応を 行い結果をFig. 5 に示した. 図から, 試料 $\mathrm{N}$ よりMの方 
Table 2 Effect of specific surface area on carbonization temperature

\begin{tabular}{|c|c|c|c|}
\hline \multirow{2}{*}{$\begin{array}{c}\text { Amount of } \\
\text { Potassium } \\
\text { in chars } \\
\text { [wt } \%]\end{array}$} & \multirow{2}{*}{$\begin{array}{l}\text { Conversion } \\
\qquad X[-]\end{array}$} & \multicolumn{2}{|c|}{$\begin{array}{l}\text { Specific surface area } \\
\text { of chars }\left[\mathrm{m}^{2} / \mathrm{kg} \text {-char }\right.\end{array}$} \\
\hline & & C.T. $500^{\circ} \mathrm{C}$ & C.T. $900^{\circ} \mathrm{C}$ \\
\hline 0 & 0.2 & $2.2 \times 10^{5}$ & $2.5 \times 10^{5}$ \\
\hline 13.2 & 0.2 & $2.6 \times 10^{5}$ & $2.8 \times 10^{5}$ \\
\hline
\end{tabular}

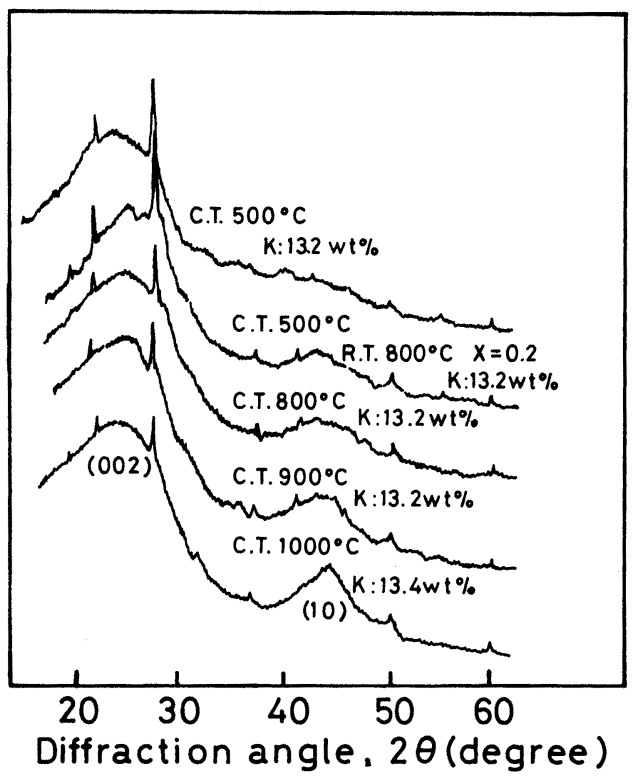

Fig.6 X-ray diffractograms of chars

がカリウム量が $1 / 2$ 程度少ないにあ関わらず同一乾留温 度での反応速度を比べた場合試料Mの反応性の方が大き い. このことは, 前述した方法により試料Mは, チャー 中への触媒の分散性が高いことと, 脱灰によって触媒と 灰成分亡の反応による触媒効果の一部の消失を防止でき たことによるあのである. しかしながら，試料 $\mathrm{N} あ \mathrm{Mむ}$ 乾留温度 $800^{\circ} \mathrm{C}$ を境にして反応性は急激に変化している. 触媒効果の異なる試料 $\mathrm{N}, \mathrm{M}$ 乾留温度 $1000^{\circ} \mathrm{C} と 800^{\circ} \mathrm{C}$ 以下の反応速度を比べた場合試料 $N, M$ 共に $1 / 2$ 程度の低 下である. したがって, 試料 $\mathrm{N}, \mathrm{M}$ に対する乾留温度の 違いによる触媒の効果はほとんど両者同一であると見る ことができる. 同様に, 前報の無触媒処理チャーについ

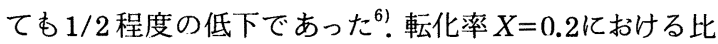
表面積むほぼ一定である. 以上の結果から, 乾留温度の 違いによるガス化反応性の差はチャー構造の状態变化が 起因しているものと見なされるのでチャー構造について 以下の検討を行った.
Table 3 Effect of carbonization temperature on crystallite size

\begin{tabular}{|c|c|c|c|}
\hline $\begin{array}{l}\text { Carbonization } \\
\text { temperature }\end{array}$ & $\begin{array}{l}\text { Cryst } \\
\text { size }[\mathrm{r}\end{array}$ & $\begin{array}{ll}\text { llite } & \mathrm{Ir} \\
\mathrm{m} \text { ] } & \mathrm{d}\end{array}$ & $\begin{array}{l}\text { terlayer } \\
\text { stance }\end{array}$ \\
\hline$\left[{ }^{\circ} \mathrm{C}\right]$ & $\begin{array}{c}\text { a-axis } \\
{[L a]}\end{array}$ & $\begin{array}{c}c-\operatorname{axis} \\
{[L c]}\end{array}$ & $d_{002}[\mathrm{~nm}]$ \\
\hline $\begin{array}{c}500 \\
\text { (R.T. } 800)\end{array}$ & 1.28 & 1.42 & 0.38 \\
\hline 800 & 1.25 & 1.45 & 0.38 \\
\hline 900 & 1.70 & 1.51 & 0.38 \\
\hline 1000 & 2.31 & 1.40 & 0.38 \\
\hline
\end{tabular}

チャー構造の変化, すなわち, 微晶質炭素を定量的に 評価するパラメータ, 結晶子を構成する炭素網目面の広 がり $L a$, 積層高さ $L c$, 層間隔 $d_{002}$ X線回折パターン からWarrenの方法 ${ }^{3)} に よ り$ 求めた。 各乾留温度に対す る $L a, L c$ および $d_{002}$ を Fig.6の (10)面, (002)面から求 め結果をTable 3 に示した，表から，本実験のような乾 留温度 $1000^{\circ} \mathrm{C}$ 以下では微晶質炭素の積層高さ $L c$ 層 間隔 $d_{002}$ は乾留温度に関係なく一定であるのに対し, 乾 留温度 $1000^{\circ} \mathrm{C}$ に打ける炭素網目面の広がり $L a$ すなお ち結晶子の成長は乾留温度 $800^{\circ} \mathrm{C}$ に比べて 2 倍程度発達 している. また $L a=1.2 \mathrm{~nm}, L a=2.3 \mathrm{~nm}$ から推算される 微晶質炭素の構成原子はそれぞれ 45,170 程度に相当する と報告されている2!

チャー構造は非常に複雑であるため微晶質炭素の構成 原子の結合状態を定量的に表し反応速度との関係を論ず ることは困難である，処理したチャ一の反応性の低下に ついて, 考えられるいくつかの原因の中からチャ一比表 面積と結晶子の成長の 2 つを取り上げて検討した結果, 比表面積ではなく, 結晶子の成長の方の可能性が大きい と判断される.

\section{Literature cited}

1) Chin, G., S. Kimura, S. Tone and T. Otake: $J$. Japan Petrol, Inst., 25, 248 (1982)

2) Diamond, R., : Acta Cryst, 10, 359 (1957)

3) Egi,K.: Shigen Gijutu Shikenjo Houkoku, 57 (1962)

4) Kojima, T., T. Furusawa and D. Kunii: Kagaku Kogaku Ronbunsyu, 10, 596 (1984)

5) Otake, T., S. Tone and S. Kimura: J. Chem. Eng . Japan, 17, 503 (1984)

6) Shimada, K. and H. Hara: Kagaku Kogaku Ronbunsyu, 9, 223 (1983)

7) Takarada, K. and Y. Otsuka: Nenryo Kyokaishi, 62, 414 (1983)

8) Veraa, M. J. and A. T. Bell: Fuel, 57, 194 (1978) 


\title{
Steam Gasification of Char Treated with $\mathrm{KOH}$ in a Fluidized Bed
}

\author{
Koji Shimada, Atsushi Sawai and Hiroshi Hara \\ Dept. of Chem. Eng., Muroran Inst. of Tech., Muroran 050
}

Key Words : Coal Gasification, Catalyst, Fluidized Bed, Carbonization, Coal Char, Steam

The effects of carbonization treatment and of catalyst addition on the reactivity of chars were studied.

Steam gasification of coal chars treated at a carbonization temperature of 500 $1000^{\circ} \mathrm{C}$ with $0-19.8 \mathrm{wt} \%$ potassium was carried out in a fluidized bed at $800^{\circ} \mathrm{C}$.

The reactivity of the chars treated at less than $800^{\circ} \mathrm{C}$ was superior to those treated at more than $900^{\circ} \mathrm{C}$.

The crystal structure of the chars was measured by X-ray diffraction, and the specific surface area of the chars by B.E.T. method.

It seems more probable that the difference in char reactivity is not caused by the specific surface area of chars but rather to their structural structure change, that is, the crystallite growth of the hexagon layer planes.

\section{電気浸透脱水過程におけるスラッジ層の平均含水率 ${ }^{\dagger}$}

\author{
吉 田 裕 志 \\ 小山工業高等専門学校 工業化学科 \\ 油川博 \\ 群馬大学工学部 化学工学科 ${ }^{\dagger+}$
}

機械的操作による脱水が困難なスラッジに対して電気 浸透脱水法は有用である ${ }^{2,5 ~ 8)}$. 電気浸透脱水に関しては 比較的多くの研究が行われてきた ${ }^{13)}$ が, 脱水機構を考慮 した理論的研究は極めて少ない. スラッジの脱水操作を 行う場合, スラッジ層の含水率の経時変化および最終含 水率を知ることが重要な問題となるが, 電気浸透脱水過

† 1986年 6 月 5 日受理

H F 323 小山市大字中久喜 771

TH T376 桐生市天神町 1-5-1

* 定電流条件における電気浸透脱水では, 脱水の進行に伴 て印加電圧が減少傾向 ( 1 次的脱水期間 ) 加ら逆に増加す るようになって消費電力の大きい 2 次的脱水過程に移行す る. 乙の 2 次的脱水期間では, 脱水量の急増とともに, ジュール熱によるスラッジの乾燥やクラックの生成などの 複雑な現象を伴う ${ }^{5,6)}$.
程に抢けるスラッジ層の平均含水率の推定方法について はこれまでほとんよ゙報告されていない。

本報では, 定電流条件の基での圧縮性スラッジの電気 浸透脱水過程に打りるスラッジ層の平均含水率について, 層の高さに実際の長さを表す変数を用いて理論的解析を 行った. 得られた理論式に立脚して, 脱水終了時の全脱 水量およびスラッジ層高を用いるてとによって, 平均含 水率を近似推定できる実験式を得た．実験式による計算 值と実測値との比較検討から, 定電流条件での電気浸透 脱水における平均含水率の経時変化がほぼ推定できるこ とを示した. ただし， 2 次的な脱水過程*については考慮 していない.

理論的考察

1) 基礎式 電気浸透脱水過程に打ける圧縮性ス 